\title{
Recruitment of shore crabs Carcinus maenas on tidal flats: mussel clumps as an important refuge for juveniles
}

\author{
M. Thiel ${ }^{1,2 *} \&$ T. Dernedde ${ }^{1,3}$ \\ ${ }^{1}$ Biologische Anstalt Helgoland, Wattenmeerstation Sylt; D-25992 List, \\ Federal Republic of Germany \\ ${ }^{2}$ Universität Kiel, Zoologisches Institut, Arbeitsgruppe Marine Ökologie und Systematik; \\ Olshausenstr. 40-60, D-24118 Kiel, Federal Republic of Germany \\ ${ }^{3}$ Universität Kiel, Institut für Haustierkunde; Olshausenstr. 40-60, D-24118 Kiel, \\ Federal Republic of Germany
}

\begin{abstract}
During the late summer and early fall, juvenile shore crabs (Carcinus maenas L.) occurred in high abundances in mussel clumps scattered on tidal flats of the Wadden Sea. Abundances were much lower on bare tidal flats without mussel clumps and decreased substantially from July to November, whereas numbers in mussel clumps remained high. Large crabs left the tidal flats in early fall, whereas juveniles undertook tidal migrations only in the late fall. In March very few shore crabs were found in the intertidal area. The size of juvenile shore crabs living between mussels did not increase significantly during fall. On the bare tidal flats surrounding the mussels, a size increase was observed. Mussel beds and mussel clumps serve as a spatial refuge for the early benthic phases of juvenile shore crabs. Between mussels they can hide effectively from their epibenthic predators. Juvenile shore crabs do not leave the intertidal area and the mussel habitats before their major predators have left the area. Mussel clumps scattered over the tidal flats may be a critical refuge for juvenile shore crabs settling on tidal flats. Intensified efforts in mussel culturing in the European Wadden Sea during recent decades may have caused an increased abundance of mussel clumps on tidal flats, thus enhancing habitat availability for some mussel-clump inhabitants.
\end{abstract}

\section{INTRODUCTION}

One of the most important predators on tidal flats, the shore crab Carcinus maenas itself suffers from heavy predation pressure by large epibenthic predators (Reise, 1985). Shore crabs are prey of fishes and various shorebirds, e.g. redshanks, greenshanks, curlews, eiders and gulls (Zwarts, 1981; Reise, 1985; Nehls, 1991; Dernedde, 1992, 1993; Dumas \& Witman, 1993). Juvenile shore crabs and post-moult individuals are susceptible to intraspecific predation. High abundances of juvenile shore crabs can be found in the high intertidal, despite the risk of physiological stress resulting from large fluctuations in temperature and salinity in this zone. However, predation pressure from adult stages of shore crabs, shrimps or fishes is depressed in the high intertidal (Günther, 1990). The small-sized juvenile shore crabs (1-10 mm carapace width) are mainly prey of the latter epibenthic predators reaching the tidal flats during high tide, whereas the adult shore

\footnotetext{
• Present address: Darling Marine Center, University of Maine, Walpole ME 04573, USA.
} 
crabs are common prey items for shore birds, especially gulls. Small gulls (Larus ridibundus, Larus canus) feed preferentially on medium-sized shore crabs (10-30 mm carapace width). The herring gull (Larus argentatus) feeds almost exclusively on largesized crabs (30-55 mm carapace width), if these are available (Dernedde, 1992, 1993).

High densities of shore crabs are reported from mussel and seagrass beds, whereas numbers in featureless sedimentary habitats are low (Klein-Breteler, 1976a; Reise, 1985). This implies that shore crabs, like other invertebrates, benefit from protection in such highly structured habitats as mussel or seagrass beds (see also Summerson \& Peterson, 1984; Reise, 1985; Mattila, 1992). The availability of spatial refuges is particularly important to decapod crustaceans during their early benthic phases (Heck \& Thoman, 1981; Armstrong \& Gunderson, 1985; Wilson et al., 1986; Orth \& Montfrans, 1987; Barshaw \& Bryant-Rich, 1988; Wahle \& Steneck, 1991, 1992).

Mussel beds (Mytilus edulis) and seagrass beds (Zostera noltii) are restricted to certain zones within a tidal basin and may be absent in large areas of the European Wadden Sea (see Dijkema, 1989). They rarely cover more than a few percent of the intertidal areas, but play an important role in the settlement of the first benthic phases of C. maenas. High densities of C. maenas within mussel beds occur immediately after larval settlement (Klein-Breteler, 1976a; Eriksson \& Edlund, 1977).

Most mussel beds are located at the low-tide line (Nehls \& Thiel, 1993), but in many parts of the European Wadden Sea small clumps of mussels are scattered over the tidal flats. Because many small animals are associated with mussel clumps (Tsuchiya \& Nishihira, 1985; Thiel \& Reise, 1993), we surmised that these clumps may serve as a spatial refuge for juvenile shore crabs. The spatial distribution of shore crabs with respect to mussel clumps as a micro-habitat was, therefore, a major focus of our study. In earlier studies it has been assumed that juvenile shore crabs remain in the intertidal area during the winter months (Atkinson \& Parsons, 1973; Klein-Breteler, 1976b; Scherer \& Reise, 1981; Reise, 1985). Sampling for our study was extended into the winter to examine the temporal distribution pattern of juvenile shore crabs in the intertidal area.

The objectives of this study were to examine the habitat use within the intertidal region by juvenile shore crabs during their first months of benthic life, and to determine whether a seasonal habitat shift takes place. On the basis of our results, we discuss the increase of the shore crab population in the study area during the last few decades (cf. Riesen \& Reise, 1982; Reise \& Schubert, 1987; Reise et al., 1989)

\section{MATERIAL AND METHODS}

This study was carried out in the Nord-Sylter Wattenmeer in the northern part of the European Wadden Sea (Fig. 1). The abundance of shore crabs was determined along two transects from the high intertidal to the low tide line, with four stations in the Oddewatt and three stations in the Nilönnwatt (Fig. 1). Quantitative sediment samples with a surface area of $500 \mathrm{~cm}^{2}$ were taken with a metal corer to a depth of about $15 \mathrm{~cm}$. Two sample types were distinguished: sediment with mussel clumps and sediment without mussel clumps. Samples without mussel clumps contained only the sediments, with the exception of the samples from the high intertidal in the Nilönnatt, which contained considerable amounts of seagrass. At each station, 6 samples of each sample type $(6+6)$ were taken. Both sample types (with and without mussel clumps) were sieved through a 


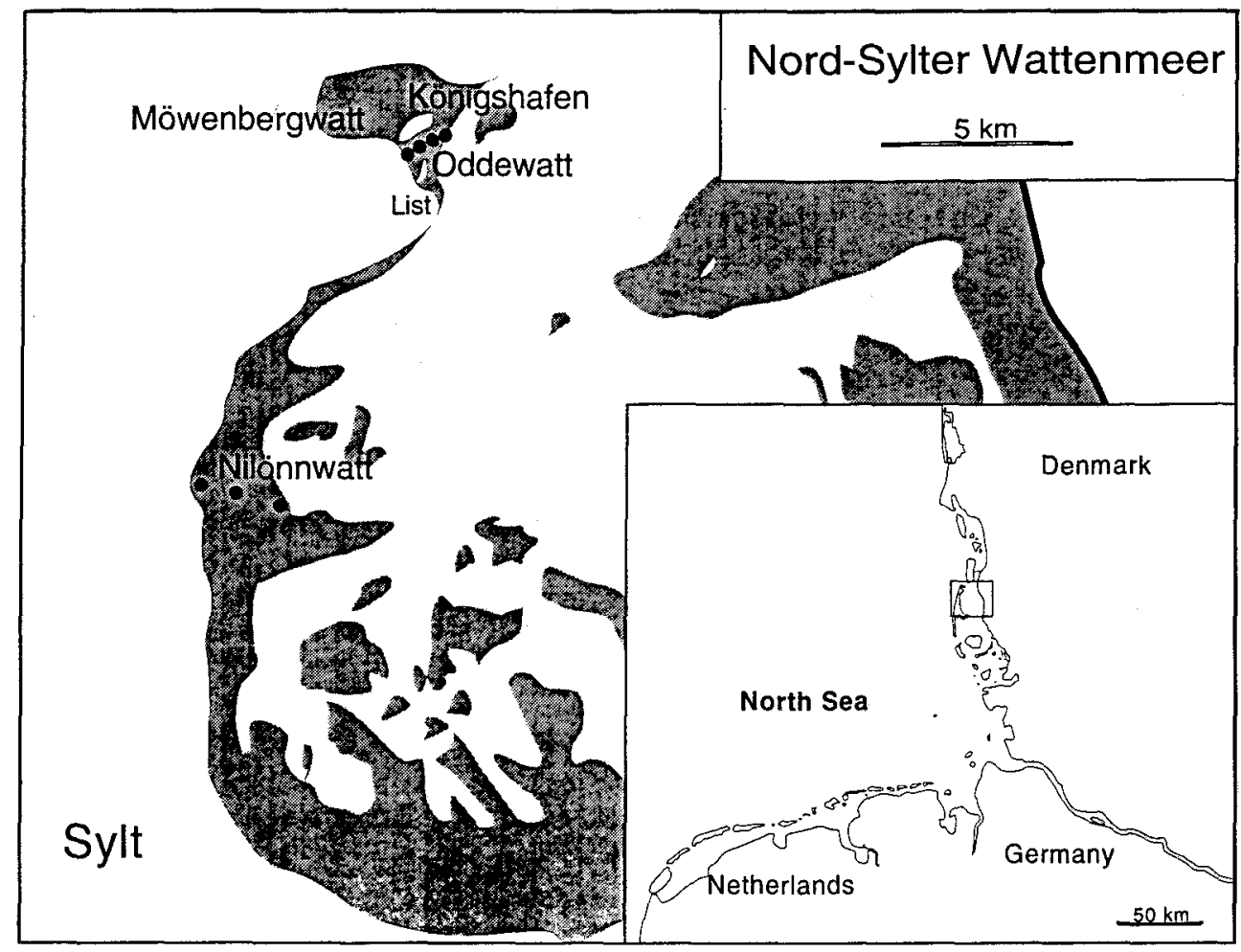

Fig. 1. Study area 'Nord-Sylter Wattenmeer' with the two transects Nilönnwatt and Oddewatt; intertidal areas are shaded.

$1000-\mu \mathrm{m}$ mesh sieve for macrofauna. All shore crabs found in these samples were counted. The Nilönnwatt transect was sampled only once in July / August 1991, whereas the Oddewatt transect was sampled in July 1991, November 1991 and March 1992. The Mann-Whitney U-test (Zar, 1984) was used to determine whether there was a significant difference in shore crab numbers between samples with and without mussel clumps.

To investigate whether juvenile shore crabs from the mussel bed and those from the surrounding bare sediment differed in size, the size-frequency of shore crabs in the mussel beds of the Oddewatt was examined between August and November 1991. Juvenile shore crabs were collected with a metal corer $\left(500 \mathrm{~cm}^{2}\right)$ from bare sediments without blue mussels and from samples taken within the mussel bed. The carapace width was taken as a measure of size (see Dernedde, 1992). To test whether significant size changes occurred during the sampling period, we applied a one-way ANOVA, followed by a post-hoc Tukey-test (Zar, 1984).

Between August and November 1991, shore crabs migrating onto the tidal flats during the high tide were collected in 10-litre bucket traps in the Möwenbergwatt (Fig. 1). Buckets with an opening diameter of $28 \mathrm{~cm}$ were dug into the sediment at the low-tide line immediately before the tide returned. The upper edge of the buckets was flush with the sediment surface. When the buckets became exposed at the next low tide, 
shore crabs were removed from the buckets and their carapace width was measured. Buckets were left exposed for a night high tide and the subsequent day high tide.

\section{RESULTS}

In July 1991 we found very high numbers of shore crabs within mussel clumps in both transects (Figs 2,3). In the seagrass bed in the high intertidal of the Nilönnwatt transect, young shore crabs reached about the same abundances as in the mussel clumps at this station (Fig. 2). No significant differences in shore-crab abundances between the mussel clumps in the seagrass bed and the surrounding seagrass bed area could be found

\section{sediment without mussel clumps}

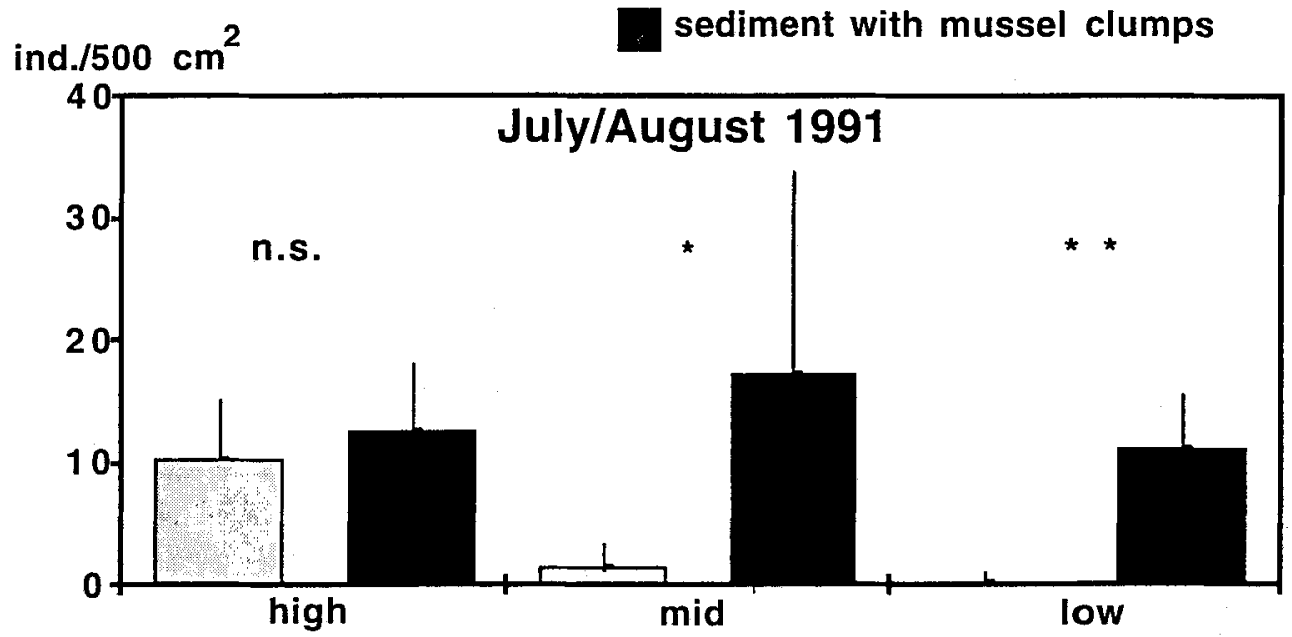

Fig. 2. Abundance of shore crabs (Carcinus maenas) in sediment samples, some containing mussel clumps and others without mussel clumps, at 3 stations of the Nilönnwatt transect. Stations are located in the high, mid and low intertidal zone, respectively. At each station, $6+6$ samples of $500 \mathrm{~cm}^{2}$ were taken and sieved with a $1000-\mu \mathrm{m}$-mesh sieve. Lines above the boxes represent one standard deviation; statistical differences between samples: n.s. not significant, $\left(^{*}\right) \quad p<0.1$, ${ }^{*} \mathrm{p}<0.05, \cdots p<0.01$

(Mann-Whitney U-test, $\mathrm{p}>0.1$ ). In contrast, there were significantly fewer shore crabs on the bare tidal flats in the mid and low intertidal than in the mussel clumps at these stations (Mann-Whitney U-test, $p<0.05$; see Fig. 2). Abundances of shore crabs in mussel clumps of the three stations were similar.

High abundances of shore crabs were also found in mussel-clump samples of the Oddewatt transect (Fig. 3). Between July and November 1991, shore crab numbers on the featureless tidal flats decreased and remained low until March 1992. Shore crab numbers in the mussel-clump samples from the high and low intertidal increased until November, but declined strongly between November 1991 and March 1992 (Fig. 3).

The average size of juvenile shore crabs from the bare tidal flats increased significantly between August and September 1991 (one-way ANOVA, followed by Tukey-test, 


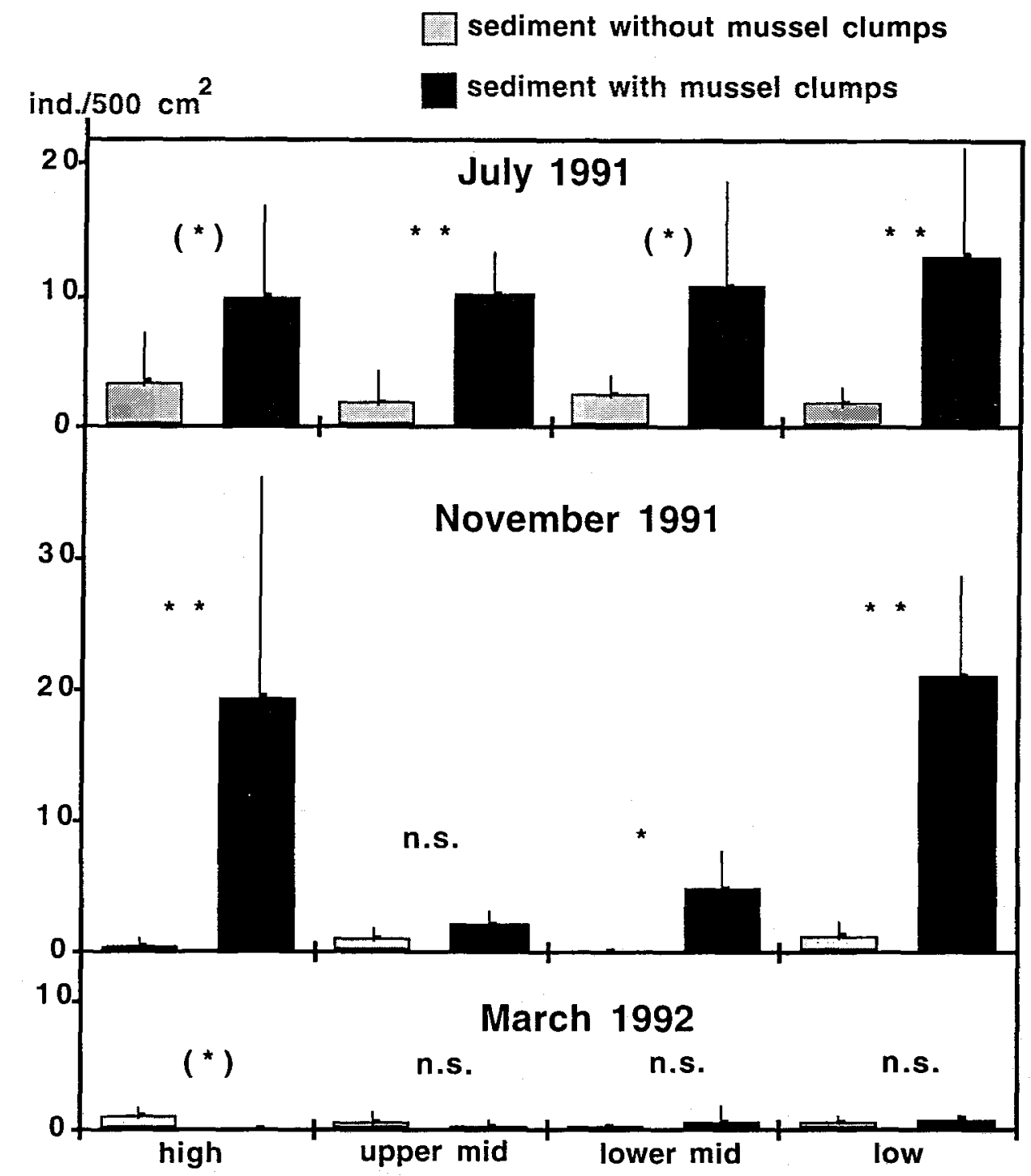

Fig. 3. Abundance of shore crabs (Carcinus maenas) in sediment samples, some containing mussel clumps and others without mussel clumps, at 4 stations of the Oddewatt transect. Stations are located in the high, upper and lower mid, and low intertidal zone, respectively. See also legend to Figure 2

$\mathrm{p}<0.05)$, whereas in the mussel bed between August and November 1991 no significant size change could be observed (one-way ANOVA, $p>0.05$; Fig. 4).

During the summer months large crabs were predominant within the bucket traps, but they started to decrease in numbers in September 1991 (Fig. 5). A shift in the relative numbers of small and large shore crabs occurred in the autumn, and in November the majority of shore crabs collected in the buckets were juvenile-stage crabs (Fig. 5). 


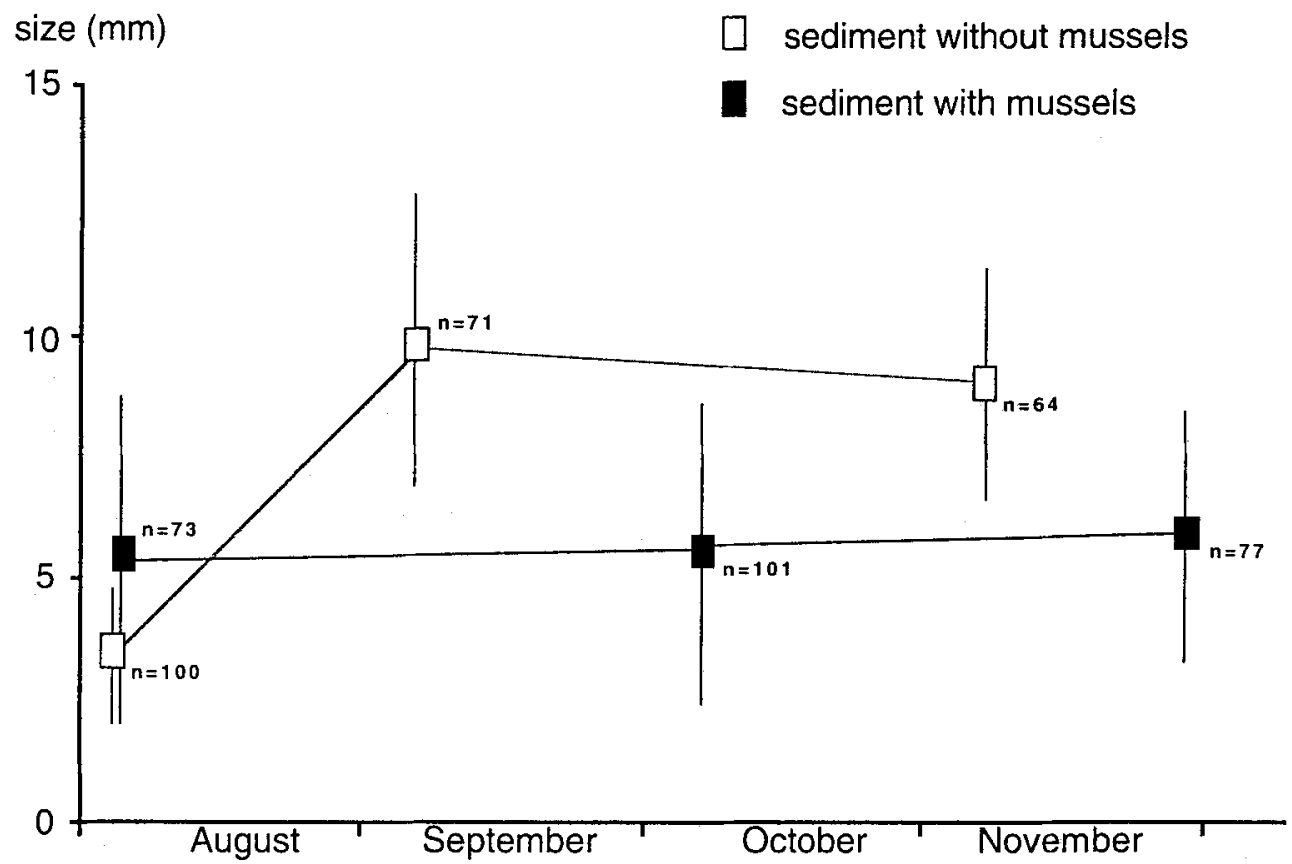

Fig. 4. Average size of shore crabs (Carcinus maenas) collected in sediment samples containing mussels and without mussels. Samples were taken in the mussel bed of the Oddewatt with a metal corer and sieved with a 1000- $\mu \mathrm{m}$-mesh sieve. The average and standard deviation for each sampling date are presented; $n=$ number of juvenile shore crabs measured per sampling date

\section{DISCUSSION}

Spatial distribution of juvenile shore crabs in the early benthic phase

Juvenile shore crabs occur in high abundances (regularly $>10$ ind./500 $\mathrm{cm}^{2}$ ) in mussel clumps scattered over tidal flats, whereas abundances on bare tidal flats are low (rarely $>5$ ind. $/ 500 \mathrm{~cm}^{2}$ ). The densities which we reported from the bare tidal flats correspond with numbers provided by Klein-Breteler (1976a) and Beukema (1991) for tidal flats in the Netherlands.

Juvenile shore crabs are small enough to hide effectively between mussels (see also Albrecht \& Reise, 1994). Here they find a safe refuge for the first months of their benthic life, as is reflected by their high abundance in the mussel-bed environment (KleinBreteler, 1976a; Eriksson \& Eklund, 1977). Those settling on the bare tidal flats may suffer from intensive predation pressure by large epibenthic predators (fishes, shrimps and adult shore crabs - see e.g. Reise, 1985). This is reflected in the decreasing densities we reported from featureless tidal flats between July and November 1991. Data given by Klein-Breteler (1976b) and Beukema (1991) indicate that this strong decrease occurs regularly on sandy tidal flats as early as August and September. The abundance of juvenile shore crabs in mussel clumps did not decrease to the same extent as on the bare tidal flats between July and November 1991, thus indicating that they are better 


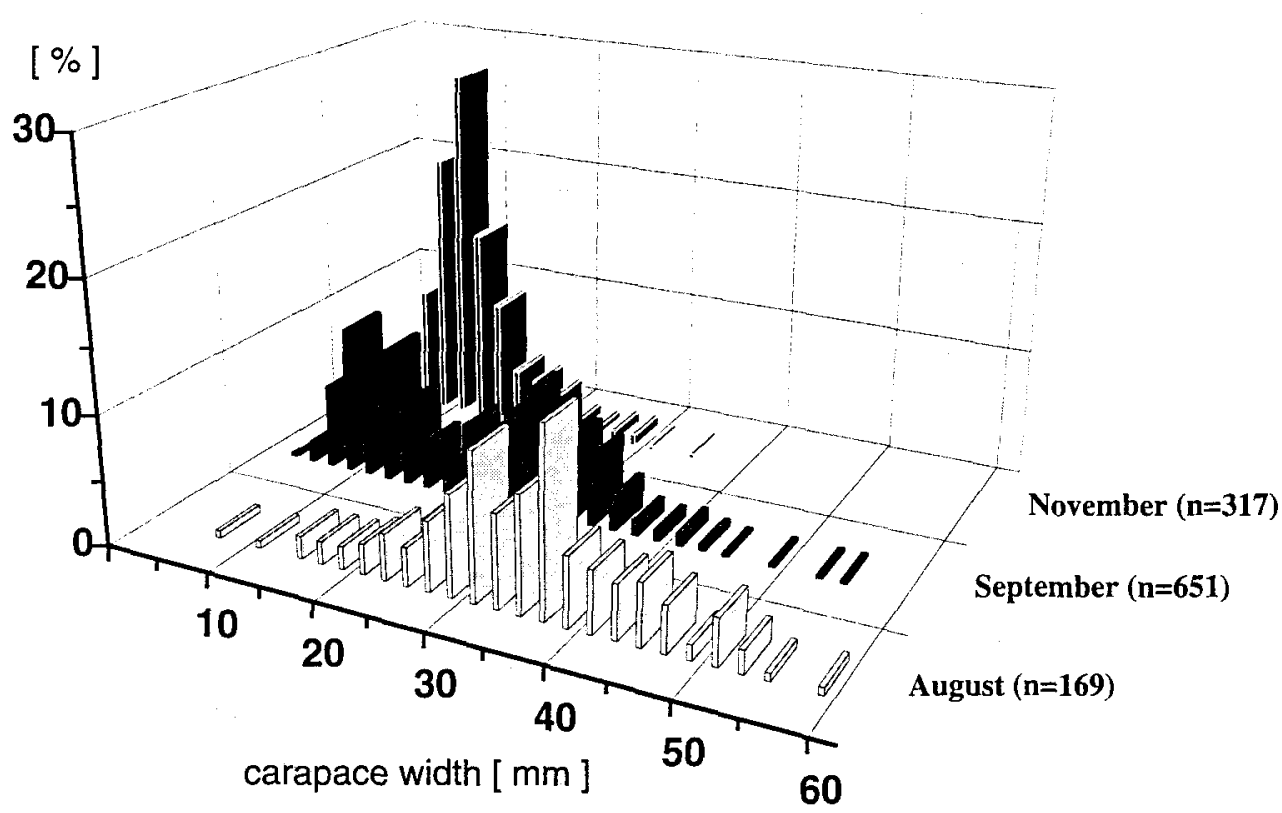

Fig. 5. Size frequency distribution of shore crabs (Carcinus maenas) collected in bucket traps during high tides at night and the subsequent day. On each sampling date, ten buckets were sunk, flush with the sediment surface, along the low-tide line immediately before the tide turned. Buckets were emptied as soon as they were exposed again after high tides

protected within the mussel clumps. Prolonged recruitment may also contribute to the relatively high abundances of juvenile shore crabs in the mussel environment during autumn (Klein-Breteler, 1976b).

During early autumn the size of shore crabs on the bare sediments increased significantly. In contrast, no increase was detectable within the mussel bed. Similarly, Klein-Breteler (1976a, see Fig. 5b) observed a much stronger size-increase in featureless sandy habitats than in mussel beds. Small stages of benthic crustaceans select small crevices, whereas larger individuals are found in less complex environments (Yoshimura \& Yamakawa, 1988; Hacker \& Steneck, 1990). Hence, the hole size and availability of interstitial spaces between mussels may be a limiting factor preventing the growing juveniles from hiding effectively in the mussel habitat (see also Wahle, 1992; Albrecht \& Reise, 1994). After reaching a certain size, juvenile shore crabs no longer fit between mussels, and consequently abandon the mussel refuge. We assume that during early autumn the growing juvenile shore crabs continuously leave the mussel beds and clumps which provided them with a spatial refuge during their early benthic phases. This spatial refuge is of major importance during the early benthic phases when juvenile shore crabs moult several times within 4 months (August-November), but the mussel bed becomes less important in late fall when moulting stops (see Bückmann \& Adelung, 1964). With the decreasing moult frequency in late autumn, juvenile shore crabs become less susceptible to intraspecific predation and enter the bare tidal flats for tidal migrations at a period when other predators, such as adult shore crabs, shrimps, shorebirds and fishes, are less 
common (Fig. 6). The shelter-providing mussel environment functions as a catalytic habitat during the recruitment of the early benthic phases of the shore crab (Fig. 6).

\section{Late emigration of juvenile shore crabs from the intertidal area}

Juvenile shore crabs.were first found in the bucket traps in September, when the largest adults started to leave the intertidal zone. During this time they are still susceptible to waders and small gulls (i.e. black-headed and common gulls), which show a

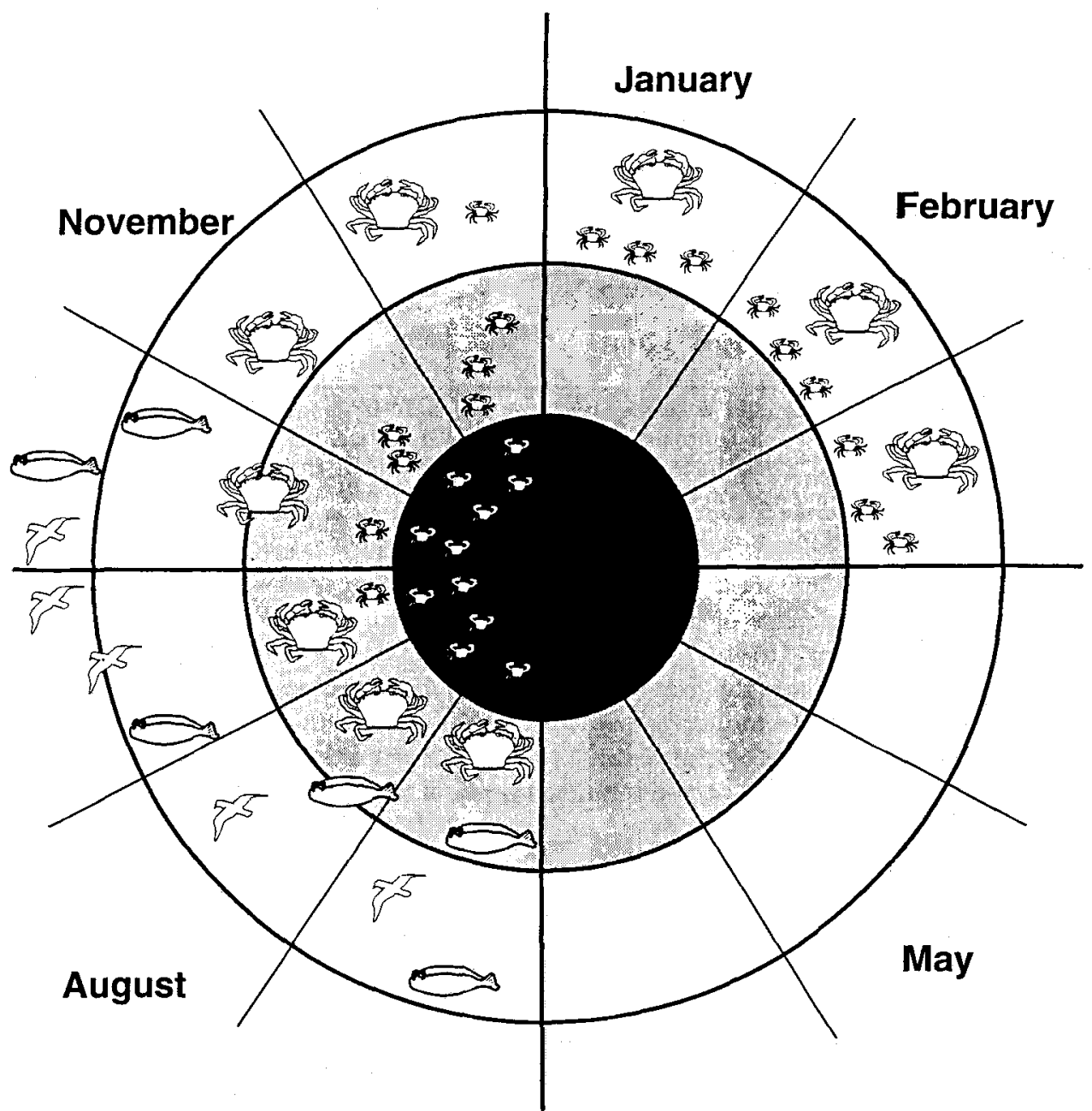

Fig. 6. Life conditions of juvenile shore crabs (Carcinus maenas) in the Wadden Sea during their first year. Mussel clumps (dark shading) in the intertidal zone (light shading) constitute a spatial refuge for the juvenile shore crabs during their first months of benthic life. Juvenile shore crabs undertake tidal migrations after their major predators have left the intertidal area. This period of decreased predation in the intertidal constitutes a temporal refuge for the juvenile shore crabs. All stages of the shore crab population spend the winter in the subtidal waters (no shading) 
preference for smaller shore crabs (Zwarts, 1981; Dernedde, 1992, 1993). The majority of gulls leave the northern parts of the European Wadden Sea after September, with only very few gulls present in October (Busche, 1980; Kempf et al., pers. comm.). In October, the large epibenthic predators of juvenile shore crabs (fishes, shrimps and adult shore crabs) have also left the tidal flats (Hüttel, 1984). Almost exclusively juvenile shore crabs were found in the bucket traps in November. This suggests that they do not suffer from predation by large epibenthic predators during this period as they do in early autumn.

The discernible increase in the numbers of juveniles in the bucket traps may result largely from decreasing predation pressure by adult shore crabs in autumn. Simple bucket traps, such as those used in our study, may distort the natural situation, as intraspecific predation among shore crabs may be intensified within the buckets. However, although predation on juvenile shore crabs may be enhanced in the bucket traps, their almost complete absence in the buckets in August shows that juvenile shore crabs do not migrate in large numbers over the bare tidal flats during the summer months.

The strong increase of juvenile shore crab numbers in the bucket traps may also be a consequence of decreasing seawater temperatures (under $5{ }^{\circ} \mathrm{C}$ in November 1991). Williams \& Naylor (1967) showed that tidal migrations by juvenile shore crabs can be induced by temperatures below $4{ }^{\circ} \mathrm{C}$. This induction of tidal migrations may also have resulted in the strong increase of juvenile shore crabs in the bucket traps in November 1991 , since seawater temperatures in the study area dropped below $5^{\circ} \mathrm{C}$ in November 1991 (Martens unpubl.). Concurrent with the increase of juvenile shore crabs apparently participating in the tidal migrations (see bucket traps), we observed a decrease of shore crabs remaining in the bare sediments during low tides (see also Beukema, 1991 Fig. 2a).

Our results indicate that juvenile shore crabs leave the intertidal area later than the adult shore crabs. This period of relatively low predation pressure in the bare tidal flats increases the survival chances of juvenile shore crabs leaving mussel refuges. Despite occasional findings of small crabs buried in the sediment in the lower intertidal area (Armonies, Reise, pers. comm.), it is evident from our results that almost no shore crabs remain in the intertidal zone during the winter months. Juvenile shore crabs therefore do not hibernate in large numbers in the intertidal zone as was assumed by Scherer \& Reise (1981). Based on our results we suggest that they migrate into subtidal waters during the winter, but do so as late in the season as possible, when the majority of their important predators have left the tidal flats (see Fig. 6).

We cannot determine with certainty whether the majority of juvenile shore crabs suffered from unfavourable weather conditions in the intertidal area during the winter or whether they all actively left the tidal flats. However, the bucket trap data indicate that a significant proportion of the juvenile shore crabs participates in the tidal migration and stays in the subtidal waters during the preceding winter. The suppressed feeding of shore crabs in water temperatures below $7^{\circ} \mathrm{C}$ (Ropes, 1968) and their reduced activity during the winter months (Dries \& Adelung, 1982) may decrease the predation pressure on juveniles, thereby allowing the coexistence of juvenile and adult shore crabs in subtidal waters (Fig. 6). As the winter of 1991/92 was a very mild winter (Deutscher Wetterdienst, pers comm.), it can be assumed that the observed desertion of tidal flats by shore crabs occurs every winter. At the end of the winter the number of shore crabs returning to the tidal flats and their time of arrival on the tidal flats differs between years with cold winters 
and those with mild winters (Beukema, 1991). Our data suggest that not only the severity of the winter but also the onset date of cold temperatures in the autumn may influence the survival rate of juvenile shore crabs. An early temperature drop inducing the tidal migration of juvenile shore crabs (Williams \& Naylor, 1967) would expose the juveniles to a high predation risk from shorebirds or large epibenthic predators.

\section{Implication for the long-term development of the shore crab population}

An increase in mussel abundance in the Wadden Sea of Schleswig-Holstein has been indicated in some recent studies (Riesen \& Reise, 1982; Reise \& Schubert, 1987; Reise et al., 1989). Although Nehls \& Thiel (1993) could not show a significant increase of mussel bed extension in the Schleswig-Holstein Wadden Sea during the last 55 years, there has unquestionably been a huge expansion of mussel culturing in this area (Nehls \& Ruth, in prep.). The mechanical impact on natural or artificial mussel beds by the mussel fishery can produce large numbers of dislodged mussel clumps, which may then be carried shoreward by tidal currents. Once arrived in the intertidal area, many of these mussel clumps become reattached to the bottom, providing a stable micro-habitat until at least late autumn (Thiel, 1992). Without mussel clumps in the tidal flats, the early benthic phases of shore crabs would be exposed to strong predation pressure from large epibenthic predators (Reise, 1985). Tsuchiya \& Nishihira (1985) showed that the abundance of mussel-clump inhabitants increases with decreasing patch-size. Mussel-harvesting activities may therefore have a positive effect on the abundance of permanent and temporary mussel-clump inhabitants by scattering large numbers of relatively small mussel clumps onto tidal flats or into subtidal waters (Reise \& Schubert, 1987; Reise et al., 1989; Nehls \& Thiel, 1993).

The long-term increase of the shore crab population in some areas of the Wadden Sea is assumed to be a result of the growth of the mussel population (Riesen \& Reise, 1982). Our data suggest that the spread of mussel clumps onto the tidal flats, resulting, in part, from mussel-harvesting activities, may enhance the survival of juvenile shore crabs in tidal flats, thereby contributing to the increase of the shore crab population in parts of the European Wadden Sea.

Acknowledgements. We thank K. Reise, S. Sampson, R. Wahle and two anonymous reviewers for many helpful comments on the manuscript. This study is supported by the Federal Environmental Agency, Environmental Research Plan of the Minister for the Environment, Nature Conservation and Nuclear Safety of the Federal Republic of Germany (Grant 108 02085/01) and by the state of Schleswig-Holstein. This is publication no. 132 of the project Ecosystem Research Wadden Sea.

\section{LITERATURE CITED}

Albrecht, A: \& Reise, K., 1994. Effects of Fucus vesiculosus covering intertidal mussel beds in the Wadden Sea. - Helgoländer Meeresunters. 48, 243-256.

Armstrong, D. A. \& Gunderson, D. R., 1985. The role of estuaries in Dungeness crab early life history: a case study in Grays Harbor, Washington. In: Proceedings of the Symposium on Dungeness crab biology and management. Ed. by B. R. Melteff. Univ. of Alaska, Fairbanks, 145-170.

Atkinson, R. \& Parsons, A. J., 1973. Seasonal patterns of migration and locomotor rhythmicity in populations of Carcinus. - Neth. J. Sea Res. 7, 81-93. 
Barshaw, D. E. \& Bryant-Rich, D. R., 1988. A long-term study on the behavior and survival of early juvenile American lobster, Homarus americanus, in three naturalistic substrates: eelgrass, mud and rocks. - Fish. Bull. 86, 789-796.

Beukema, J. J., 1991. The abundance of shore crabs Carcinus maenas (L.) on a tidal flat in the Wadden Sea after cold and mild winters. - J. exp. mar. Biol. Ecol. 153, 97-113.

Bückmann, D. \& Adelung, D., 1964. Der Einfluß der Umweltfaktoren auf das Wachstum und den Häutungsrhythmus der Strandkrabbe Carcinides maenas. - Helgoländer wiss. Meeresunters. 10, 91-103.

Busche, G., 1980. Vogelbestände des Wattenmeeres von Schleswig-Holstein. Kilda-Verl., Greven, $155 \mathrm{pp}$.

Dernedde, T., 1992. Untersuchungen zur Ernährung der Möwen im Königshafen auf Sylt. Dipl.Arb., Univ. Kiel, $92 \mathrm{pp}$.

Dernedde, T., 1993. Vergleichende Untersuchungen zur Nahrungszusammensetzung von Silbermöwe (Larus argentatus), Sturmmöwe (L. canus) und Lachmöwe (L. ridibundus) im Königshafen/ Sylt. - Corax 15 (3), 222-240.

Dijkema, K. S., 1989. Habitats of the Netherlands, German and Danish Wadden Sea. Research Institute for Nature Management/Veth foundation, Texel. 30pp.

Dries, M. \& Adelung, D., 1982. Die Schlei, ein Modell für die Verbreitung der Strandkrabbe Carcinus maenas. - Helgoländer Meeresunters. 35, 65-77.

Dumas, J. V. \& Witman, J. D. 1993. Predation by herring gulls (Larus argentatus Coues) on two rocky intertidal crab species (Carcinus maenas [L.] \& Cancer irroratus Say). - J. exp. mar. Biol. Ecol. $169,89-101$.

Eriksson, S. \& Edlund, A.-M., 1977. On the ecological energetics of 0-group Carcinus maenas (L.) from a shallow sandy bottom in Gullmar Fjord, Sweden. - J. exp. mar. Biol. Ecol. 30, 233-248.

Günther, C.-P., 1990. Distribution patterns of juvenile macrofauna on an intertidal sandflat: an approach to the variability of predator/prey interactions. In: Trophic relationships in the marine environment. Ed. by M. Barnes \& R. N. Gibson. Aberdeen Univ. Press, Aberdeen, 77-88. (Proc. 24 th Europ. Mar. Biol. Symp.)

Hacker, S. D. \& Steneck, R. S., 1990. Habitat architecture and the abundance and body-sizedependent habitat selection of a phytal amphipod. - Ecology 71, 2269-2285.

Heck, K. L. \& Thoman, T. A., 1981. Experiments on predator-prey interactions in vegetated aquatic habitats. - J. exp. mar. Biol. Ecol. 53, 125-134.

Hüttel, M., 1984. Zur Ökologie aasfressender Wattbewohner - Untersuchungen an Carcinus maenas und Anaitides maculata. Dipl.Arb., Univ. Kiel, 84 pp.

Klein-Breteler, W. C. M., 1976a. Migrations of the shore crab, Carcinus maenas, in the Dutch Wadden Sea. - Neth. J. Sea Res. 10, 338-353.

Klein-Breteler, W. C. M., 1976b. Settlement, growth and production of the shore crab, Carcinus maenas, on tidal flats in the Dutch Wadden Sea. - Neth. J. Sea Res. 10, 354-376.

Mattila, J., 1992. The effect of habitat complexity on predation efficiency of perch Perca fluviatilis L. and ruffe Gymnocephalus cernuus (L.). - J. exp. mar. Biol. Ecol. 157, 55-67.

Nehls, G., 1991. Bestand, Jahresrhythmus und Nahrungsökologie der Eiderente, Somateria mollissima, L. 1758 im Schleswig-Holsteinischen Wattenmeer. - Corax 14, 146-206.

Nehls, G. \& Thiel, M., 1993. Large-scale distribution patterns of the mussel Mytilus edulis in the Wadden Sea of Schleswig-Holstein: do storms structure the ecosystem? - Neth. J. Sea Res. 31, $181-187$.

Orth, R. J. \& Montfrans, J. van, 1987. Utilization of a seagrass meadow and tidal marsh creek by blue crabs Callinectes sapidus. I. Seasonal and annual variations in abundance with emphasis on post-settlement juveniles. - Mar. Ecol. Prog. Ser. 41, 283-294.

Reise, K., 1985. Tidal flat ecology. Springer, Berlin, $191 \mathrm{pp}$.

Reise, K. \& Schubert, A., 1987. Macrobenthic turnover in the subtidal Wadden Sea: the Norderaue revisited after 60 years. - Helgoländer Meeresunters. 41, 69-82.

Reise, K., Herre, E. \& Sturm, M., 1989. Historical changes in the benthos of the Wadden Sea around the island of Sylt in the North Sea. - Helgoländer Meeresunters. 43, 417-433.

Riesen, W. \& Reise, K., 1982. Macrobenthos of the subtidal Wadden Sea: revisited after 55 years. Helgoländer Meeresunters. 35, 409-423.

Ropes, J. W., 1968. The feeding habits of the green crab Carcinus maenas. - Fish. Bull. 67, $183-203$. 
Scherer, B. \& Reise, K., 1981. Significant predation on micro- and macrobenthos by the crab Carcinus maenas L. in the Wadden Sea. - Kieler Meeresforsch. (Sonderh.) 5, 490-500.

Summerson, H. C. \& Peterson, C. H., 1984. Role of predation in organizing benthic communities of a temperate-zone seagrass bed. - Mar. Ecol. Prog Ser. 15, 63-77.

Thiel, M., 1992. Zur Ökologie von Nemertinen im Wattenmeer. Dipl.Arb., Univ. Kiel. 69 pp.

Thiel, M. \& Reise, K., 1993. Interaction of nemertines and their prey species on tidal flats. - Neth. J. Sea Res. 31, 163-172.

Tsuchiya, M. \& Nishihira, M., 1985. Islands of Mytilus as a habitat for small intertidal animals: effect of island size on community structure. - Mar. Ecol. Prog. Ser. 25, 71-81.

Wahle, R. A., 1992. Substratum constraints on body size and the behavioral scope of shelter use in the American lobster. - J. exp. mar. Biol. Ecol. 159, 59-75.

Wahle, R. A. \& Steneck, R. S., 1991. Recruitment habitats and nursery grounds of the American lobster Homarus americanus: a demographic bottleneck? - Mar. Ecol. Prog. Ser. 69, 231-243.

Wahle, R. A. \& Steneck, R. S., 1992. Habitat restrictions in early benthic life: experiments on habitat selection and in situ predation with the American lobster. - J. exp. mar. Biol. Ecol. 157, 91-114.

Williams, B. G. \& Naylor, E., 1967. Spontaneously induced rhythm of tidal periodicity in laboratoryreared Carcinus. - J. exp. Biol. 47, 229-234.

Wilson, K. A., Heck, K. L. \& Able, K. W. 1986. Juvenile blue crab, Callinectes sapidus, survival: an evaluation of eelgrass, Zostera marina, as refuge. - Fish. Bull. 85, 53-58.

Yoshimura, T. \& Yamakawa, H., 1988. Microhabitat and behavior of settled pueruli and juveniles of the Japanese spiny lobster Panulirus japonicus at Kominato, Japan. - J. crust. Biol. 8, 524-531.

Zar, J. H., 1984. Biostatistical analysis. Prentice-Hall, New Jersey, $718 \mathrm{pp}$.

Zwarts, L., 1981. Habitat selection and competition in wading birds. In: Ecology of the Wadden Sea. Ed. by W. J. Wolff. Balkema, Rotterdam, 271-279. 